\title{
ENDOGENOUS INTOXICATION AND INFLAMMATION: REACTION SEQUENCE AND INFORMATIVITY OF THE MARKERS

\author{
(review)
}

\section{V.I. SIDEL'NIKOVA, A.E. CHERNITSKIY, M.I. RETSKY}

All-Russian Research Veterinary Institute of Pathology, Pharmacology and Therapy, Russian Academy of Agricultural Sciences, 114-b, ul. Lomonosova, Voronezh, 394087 Russia, e-mail cherae@mail.ru, retsky@mail.ru Received March 24, 2014

\section{Abstract}

According to modern phylogenetic theory of general pathology (V.N. Titov, 2003, 2013) inflammation is a nonspecific biological reaction, providing the removal of excessive amount of highmolecular macromolecules and maintenance of metabolic homeostasis (endoecology). The increase of any metabolite concentration above the physiological range is a violation of the «purity» of intercellular medium. This triggers two nonspecific biological reactions, namely the excretion used to remove «biological waste» of a molecular weight less than $70 \mathrm{kD}$ and the inflammation in case the larger molecules and their complexes should be removed via neutrophils, resident macrophages and endothelial cells. Blood concentration of leukocytes has been used for evaluation of inflammation and intoxication activity for many decades. However, at the molecular level there is a requirement in precise differentiation of metabolites, activating leukocytes, and metabolites, excessively forming as a result of activation, because the last disturb molecular homeostasis and may damage cells and tissues. Validity of leucocytal intoxication index (LII) of Ya.Ya. Kalf-Kalif, concentration ratio of low and medium molecular weight substances, average molecular peptides, total and effective albumin as markers of endogenous intoxication (M.Ya. Malakhova, 2005) are considered. It is shown that primary agent, activating neutrophils and some factors of humoral immunity, is a lipopolysaccharide (endotoxin) of gram-negative microflora (M.Yu. Yakovlev, 2003; O.W. McIntyre, 2011). An excess of endotoxin inflow is possible under intestine and liver pathologies, and due to sympathoadrenal system activation, and also with feed and air. The overload of systems and organs of elimination of endotoxin causes secondary immunodeficiency, which becomes the cause of acute and chronic inflammatory processes of various localizations. It is offered to consider lipopolysaccharide of gramnegative microflora as a primary agent of endogenous intoxication and all the metabolites, produces at increased concentrations as a result of polymorphonuclear leukocytes activation such as reactive oxygen species, oxidated proteins, products of lipid peroxidation and proteolysis, as a secondary one. Such an approach allows to single out various points of application for therapy of endogenous intoxication: i) elimination of excessive concentration of lipopolysaccharide in blood by limiting its production and income from internal and external sources, as well as by a variety of methods of active binding and excretion of endotoxin (S.V. Smirnov et al., 2003; K. Battenschoen et al., 2010); ii) reducing the concentration of «secondary» metabolites in blood and tissues.

Keywords: endogenous intoxication, segmentated neutrophils, lipopolysaccharides, inflammation, endotoxinemia, endoecology.

During phylogenesis, humans and animals develop a number of basic biological functions such as trophology, adaptation, homeostasis, endoecology (maintaining «purity» of the internal environment). According to the present views [1], the function of endoecology maintains homeostasis at the molecular level to keep all the metabolites and physicochemical parameters below the upper physiological limits. Any excess is perceived as the impairment to «purity» of the intercellular medium, its «littering» [2]. This triggers two nonspecific biological reactions, the excretion and inflammation. If the molecular weight of biological «waste» is less than $70 \mathrm{kDa}$ (the molecular weight cut-off of a nephron), it is removed by excretion (with or without preliminary transformation). When the molecular weight exceeds this value, cells of loose connective tissue (neutrophils, resident macrophages, endothelial cells) become involved in the disposal 
of the transformed or non-transformed metabolites (phlogogenic «waste») [3].

The first element of the above mechanism is represented by segmented neutrophils (SN) with pathogen identifying receptors [4]. Primary defense reactions are non-specific, stereotypic and the degree of their manifestation depends on the individual adaptation potential of the body. Irrespective of the trigger, the intracellular SN activation starts with a «respiratory outburst», generation of reactive oxygen species [5, 6], excretion of large amounts of enzymes [7], antimicrobial proteins [8, 9], peptides [10], and cytokines [10-12], required for the elimination of the pathogen and activation of other components of the immune system, from the inclusion granules. The success of these processes is determined by the following ratios and factors, namely the concentration and virulence of the pathogen/the count and reactivity of SN, macrophages, antimicrobial and transport proteins [5, 12]; the formation rate and concentration of pro-oxidant metabolites/the rate of inflow and concentration of antioxidants [6]; the formation rate and concentration of intermediate and end products of peroxidation and proteolysis (oxidated proteins, lipids, nucleic acids, poly- and oligopeptides)/the functional activity of their transport and elimination systems [13, 14]; the activity of pro- and anticoagulant hemostasis systems; the degree of permeability of histohematogenous barriers [15].

All the above pro- and anti-inflammatory reactions take place at different structural levels from the molecular one to the level of the whole body, with many natural metabolites forming in considerably larger amounts than normal. Thus, the efficiency of the initial intermolecular binding of a phlogogen depends on the concentration of binding and transport proteins [9]. The removal of «waste» from the cells and tissues into the blood (directly or through the lymph) is determined by the microcirculation, with hypovolaemia, sludge or disseminated intravascular coagulation resulting in the accumulation of metabolites in the intercellular space. The removal of byproducts from the bloodstream and their excretion is performed by the natural detoxification systems (liver, kidneys, gastrointestinal tract, lungs, skin) and depends on their structural and functional status $[3,15]$.

At all the structural levels, the specified processes have four development stages: stage 1 as compensation, when the excretion or neutralization systems can handle the increased concentrations of metabolites to be removed; stage 2 as stress stage, at which the rate of formation of such substances is equal to the maximum rate of their excretion (neutralization); stage 3 as subcompensation meaning that the rate of metabolite formation already exceeds the maximum rate of their excretion, and the concentration of toxins in blood increases; and finally stage 4 as decompensation, i.e. failure of detoxification systems and organs, a critical condition [15].

With acute processes, stages 3 and 4 develop quite quickly. This is the type of endogenous intoxication in cases of major burns, a crush syndrome, acute pancreatitis, and acute renal failure. However, if the excessive metabolites are formed in an avalanche-like manner, endogenous intoxication (accumulation of «waste») may not manifest itself but seriously overload different elimination systems. Moreover, the most insignificant impacts on the body (infection, any stress) can disturb the delicate equilibrium by provoking an increase in concentration of particular metabolites and, as a result, decompensation of detoxification systems. This pattern is typical both for the excretion reaction and inflammation [2].

Studying endogenous intoxication which accompanies inflammation, it is desirable to differentiate between the mechanisms behind the accumulation of primary phlogogens initiating a cascade of pro- and anti-inflammatory reactions 
and the mechanisms which govern the excessive formation of products of effector reactions of activated SN themselves, as well as markers of these processes.

Leucocytal intoxication index (LII) suggested by Y.Y. Kalf-Kalif was one of the first markers of endogenous intoxication [16]. This index represents a quantitative ratio between the total percentage of cells of granulocytic series (myelocytes, young, rod, and segmented neutrophils) and lymphocytes, monocytes, eosinophils, which is calculated using leucogram. An increase in LII can be observed in case of neutrophilia and a left shift in the leukocyte count.

Since these changes in the peripheral blood are typical for inflammations of different etiology and localization, LII reliably represents reactivity of the granulocytic system against exo- or endopathogens. This reaction is non-specific and develops in response not only to viruses, bacteria and their toxins but also to many other non-infectious factors such as physical activity, trauma, hypoxia, stress of any kind [15]. In all cases, the degree of neutrophilia depends not so much on the nature of the trigger but rather on the reactivity phase of the granulocytic system, which includes circulating and bone marrow pools of mature SN and proliferating precursor cells of the granulocytic series. In the decompensation phase, the effect of a phlogogen on the system results in neutropenia [17] and, consequently, in LII decrease despite the intoxication.

Therefore, LII and other leucocytal indices (lymphocytic, nuclear shift index, etc.) should be considered as cell markers of granulocytic system reactivity, which, in a number of cases, do not reflect any endogenous intoxication [17].

Concentrations of substances with low and middle molecular weight (LMMWS), or so-called «middle molecules» (MM), are widely taken as a molecular marker of endogenous intoxication [18, 19]. Different methods used to determine these concentrations $[13,20]$ are based on the sedimentation of high molecular weight proteins from the analyzed biological material (whole blood, blood serum, plasma, erythrocytes, urine, spinal fluid, exhaled breath condensate) applying trichloracetic acid, with the subsequent determination of optical density of the deproteinized solution at one or several wavelengths (238, 240, 254, $280 \mathrm{~nm}$ ). The term «middle molecular weight substance (molecule)» [13] means that the solution contains various unidentified chemical substances (peptides, nucleotides, products of carbohydrate, lipid, or nitrogen metabolism) with one common property - their molecular weight ranges from 300 to 5,000 Da. The optical density of the test solutions at different wavelengths makes it possible to arbitrarily group the substances based on the maximum absorption. To improve the informativity of the method, ratios of serum and erythrocyte extinctions at different wavelengths are corrected by factors, the degree of elimination of LMMWS by kidneys, and the sorption potential of erythrocytes [21, 22], as well as a number of other biochemical indices are also taken into account. Taken together, these indices make it possible to evaluate the metabolic compensatory potential of the body in case of endogenous intoxication [23].

The MM content is an integrated index but it is quite informative because it is the substances with the molecular weight of 300-5,000 Da (and primarily short-chain peptides from LMMWS pool) that are responsible for the negative effects which we generally call endogenous intoxication [20, 23]. It is the middle molecular weight peptides (MMWP), the products of proteolysis of various proteins, which is activated in case of inflammation, that can block cells receptors, bind active centers of the albumin molecule competing with regulatory peptides and thus disturbing the process of humoral regulation [14, 18]. Determination of peptides by measuring optical density of deproteinized solution of biological fluids at $\lambda=210 \mathrm{~nm}$ is a simple and much more sensitive method compared with LMMWS determination techniques [24]. This marker represents 
the activity of proteolytic processes, and in a number of cases its dynamics is different from the dynamics of LMMWS [24].

Albumin, the main transport protein of blood, is another informative marker of endogenous intoxication. Fluorimetric determination is a convenient method to determine, without any sample preparation, the total albumin concentration (TAC) and the concentration of the so-called effective albumin (EAC), which reflects the ability of a molecule to bind and transport various metabolites and drugs [25]. Under normal conditions, these values are almost the same and TAC/EAC ratio equals one. Various forms of pathology accompanied by endogenous intoxication are characterized by toxins, peptides, bilirubin and other substances blocking binding sites on albumin molecule (14). In this case albumin concentration in the blood serum does not change much but its binding capacity characterized by TAC/EAC ratio decreases and the toxicity index calculated as (TAC/EAC) - 1 increases. The intoxication coefficient (IC), which determines the balance between the accumulation and binding of metabolites and is calculated as a ratio between LMMWS or MMWP and TAC, reflects the degree of endogenous intoxication even better [26].

A major role in the inflammatory disturbance of endoecology is played by reactive oxygen species and peroxidation products, which are formed in excess amounts in case of SN activation [5, 6]. More often they are considered as markers of oxidative stress but not endogenous intoxication, although nucleic acids denaturated by oxidation, proteins and numerous products of lipid peroxidation serve as biochemical factors of the internal environment contamination and create an extra load for the natural systems of elimination. The dynamics of these metabolite concentrations reflects the efficiency of the homeostatic mechanisms at the molecular level [3].

In case of inflammation, all the above markers of endogenous intoxication reflect different blocks in the cascade of pro- and anti-inflammatory reactions triggered by activated $\mathrm{SN}$ and are considered as secondary.

According to the present views [27-32], the intestinal endotoxin (ET), which is formed when the gram-negative intestinal microflora, mainly Escherichia coli, is killed, acts as the leading agent initiating activation of SN and the entire granulocytic system and defining the similarity between the mechanisms of adaptation and pathology in case of inflammation [33-36]. This is a natural metabolite, a lipopolysaccharide (LPS) by its chemical nature. SN and a number of other cells have special toll-like receptors responsible only for the recognition of LPSs of any gram-negative bacteria [37-39]. This is a genetically fixed reaction observed in all mammals [40, 41].

LPS is constantly present in the systemic blood of healthy people and animals, and can be detected in the blood serum and $\mathrm{SN}$ in very low concentrations. This phenomenon was named the systemic endotoxinemia (SEI) [29, 30]. About $95 \%$ of ET synthesized in the intestine is bound by resident macrophages of the liver and also excreted through kidneys, mucous membranes and skin [42]. The excessive inflow of ET into blood may occur as a result of an increase in the intestinal permeability (in case of dysbiosis, inflammation of the intestinal wall) $[43,44]$, increase in the blood drain via portacaval shunting (bypassing the liver) $[45,46]$, in case of sympathoadrenal system activation or compromised detoxification function of the liver [45]. In turn, the sympathoadrenal system can get activated by all types of stress or physical exercise. Concentrations of LPS and cortisol in blood have been found to directly correlate [47]. In the systemic bloodstream, ET is bound by SN, an LPS-binding protein, or antibodies to Re-glycolipid of LPS [48]. In case of failure of LPS-eliminating systems, its concentration in blood may increase several times, which is defined as the en- 
dotoxin aggression (EA) [49-51]. If the systemic endotoxinemia represents an adaptive physiological phenomenon [27, 30], the endotoxin aggression is a general pathological phenomenon since, according to the endotoxin theory [30, 52], it is a universal agent in the development mechanisms of the majority of principal infectious [53, 54] and non-infectious diseases [55, 56], and symptom complexes. The transformation of SEI into EA undergoes all stages (from the compensation and stress to subcompensation and decompensation) typical for the development of other forms of endogenous intoxication. The essential feature here is that the decompensation stage of antiendotoxin mechanisms, which can last for years, transfers the granulocytic system to the unresponsiveness (decompensation) phase, the result of which is that any bacterial or viral microflora (even potentially pathogenic) can cause local inflammatory processes poorly controlled with conventional antibiotics treatment [57].

An increase in LPS concentration should be considered as endogenous intoxication since LPS is a natural metabolite (as distinguished from exotoxins excreted by pathogenic bacteria when they invade the human or animal body). If other metabolites in high concentrations are capable to cause multiple organ failure, LPS intoxication (endotoxin aggression) depletes the adaptation resource of cellular (SN, macrophages) and humoral (antibodies) immunity resulting in its secondary failure. This secondary failure, in turn, causes acute and chronic inflammations [58-61], which are accompanied by endogenous intoxication involving different metabolites. This vicious cycle can be successfully broken by the action on the trigger, which is the gram-negative microflora endotoxin [6266]. That requires not only identifying ET in blood but also monitoring this index during the treatment [67].

Currently, there are several methods to detect ET in biological fluids. LAL test is a classical method based on the specific interaction between the endotoxin and hemolymph of the horseshoe crab (Limulus polyphemus), with test solution transforming into gel as a result. LAL test is included in pharmacopoeias of many countries, and in 1997 it was included in the RF Pharmacopoeia (VFS 42-2960-97 Determination of Bacterial Endotoxins. LAL test). Various modifications of LAL test can be used for quantitative and qualitative determination of ET [68-70]. A method of instant diagnosis of ET in blood based on the latex particle agglutination principle has been developed [71].

Considering that ET concentration in blood is a resulting indicator of two processes, the LPS formation and LPS elimination by binding with specific proteins and cells, the intensity of these processes needs to be simultaneously assessed since the anti-endotoxin resistivity of the body plays a key role in the transition of endotoxinemia into endotoxin aggression [49, 72]. A screening system is developed to assess the immune status using enzyme-linked immunosorbent assay (SIS-ELISA) [73], in which the markers are the concentrations of antibodies to various areas of LPS and lipopolysaccharide binding protein (LBP), as well as a ratio between the indices of humoral and cellular (reserve of LPS binding by neutrophils) components of the immune system. These markers reflect the degree of overload of the indicated components, which, in turn, may result in the functional insufficiency of the immune system. Moreover, immune systems of both people and animals demonstrate unique responses to the initial and repeated contacts with LPS [67, 74].

Thus, the lipopolysaccharide (LPS) of gram-negative microflora should be considered as a natural metabolite capable of causing endogenous intoxication (endotoxin aggression) in case its inflow into the bloodstream is increased and/or the elimination rate is decreased. Firstly, causing non-specific activation of 
segmented neutrophils, LPS results in the gradual transition of the granulocytic system into the phase of decompensation and unresponsiveness to pathogenic and potentially pathogenic microflora, which, in turn, increases the risk of the development of both infectious and a number of non-infectious diseases. Secondly, as a result of $\mathrm{SN}$ activation, reactive oxygen species, peroxidation and proteolysis products are formed in excess, and they bring about the metabolic contamination and overload the natural systems of elimination. Therefore, such products should be considered as markers of the secondary (with respect to the primary, LPS induced one) intoxication. Such approach makes it possible to identify different application points for endogenous intoxication treatment. The first one is to decrease LPS concentration in blood by limitation of its generation and inflow from internal and external sources, as well as by using various methods of active binding and elimination of endotoxin. That decreases high load on natural systems of endotoxin elimination, prevents their decompensation and the development of secondary immunodeficiency. The second method is to decrease concentrations of secondary metabolites in blood and tissues (e.g. by binding excessive reactive oxygen species by antioxidants), which is less efficient but justified if it is impossible to apply the means and methods from the first group. Studying molecular markers of inflammation and endogenous intoxication also creates a basis for the development of fundamentally new anti-inflammatory pharmaceuticals.

\section{REFERENCES}

1. T i t o v V.N. Klinicheskaya i laboratornaya diagnostika, 2013, 5: 27-38.

2. Tit o v V.N., K ry 1 i n V.V. Klinicheskaya i laboratornaya diagnostika, 2010, 5: 20-26.

3. Ti t o v V.N., O s i p o v S.G. Ateroskleroz. Rol' endogennogo vospaleniya, belkov ostroi fazy $i$ zhirnykh kislot [Atherosclerosis. The role of endogenous inflammation, the acute phase proteins, and fatty acids]. Moscow, 2003.

4. Hallmann M., Ra met M., Ez e k owitz R.A. Toll-like receptors as sensors of pathogens. Pediatric Research, 2001, 50: 315-321 (doi: 10.1203/00006450-200109000-00004).

5. K $1 \mathrm{e} \mathrm{b}$ a n off S.J. Oxygen metabolites from phagocytes. In: Inflammation: basic principles and clinical correlates. J.I. Gallin, R. Snyderman (eds.). Philadelphia, 1999: 721-768.

6. F a n g F.C. Antimicrobial reactive oxygen and nitrogen species: concepts and controversies. Nat. Rev. Microbiol., 2004, 10: 820-832 (doi: 10.1038/nrmicro1004).

7. M y a nski i D.N. Khronicheskoe vospalenie [Chronic inflammation]. Moscow, 1991.

8. B o x e r L.A., C o a te s T.D., H a a k R.A. Lactoferrin deficiency associated with altered granulocyte function. N. Engl. J. Med., 1982, 7: 404-410 (doi: 10.1056/NEJM198208123070704).

9. Harde r J., Glase r R., S chrode r J.-M. Human antimicrobial proteins effectors of innate immunity. J. Endotoxin Res., 2007, 6: 313-338 (doi: 10.1177/0968051907088275).

10. B orrega a rd N., C ow la nd J.B. Granules of the human neutrophilic polymorphonuclear leukocyte. Blood, 1997, 10: 3503-3521.

11. B aggiolini M., Dewold B. Exocytosis by neutrophils. Contemp. Top. Immunobiol., 1984, 14: 221-246.

12. Condliffe A.M., Kitchen E., Chilvers E.R. Neutrophil priming: pathophysiological consequences and underlying mechanisms. Clin. Sci., 1998, 94: 461-471.

13. G a b ri e l y a n N.I., Li p a t o v a V.I. Laboratornoe delo, 1984, 3: 138-140.

14. Gavrilov V.D., Bidula M.M., Durmanchuk D.A. V sbornike: Al'bumin syvorotki krovi $v$ klinicheskoi meditsine [In: The blood serum albumin in clinical medicine]. Moscow, 1998: 132-139.

15. Vlas o v V.V. Reaktsiya organizma na vneshnie vozdeistviya: obshchie zakonomernosti razvitiya $i$ metodicheskie problemy issledovaniya [The body's response to external factors and methodological aspects of the survey]. Irkutsk, 1994: 17-18.

16. K a l'f - K a lif Ya.Ya. Vrachebnoe delo, 1941, 1: 31-35.

17. S i d e l' $\mathrm{n}$ i k ov a V.I., Li f s h its V.M. Fiziologicheskii zhurnal im. I.M. Sechenova, 1992, 5: $28-32$.

18. Vladyka A.S., Belyakov N.A., Shugaev A.I. Vestnik khirurgii im. I.I. Grekova, 1986, 8: 126-129.

19. Velik a n o v V.V., V a si le v s k a y E.M. Uchenye zapiski UO VGAVM, 2013, 49(1): 
23-26.

20. M a la k hov a M.Ya. Efferentnaya terapiya, 1995, 1: 61-63.

21. G r e b n e va O.L., T k a c h u k E.A., C hu b e i k o V.O. Klinicheskaya i laboratornaya diagnostika, 2006, 6: 17-19.

22. Kovale vs ki i A.N., N if a n t' e v O.E. Laboratornoe delo, 1989, 10: 35-39.

23. M a la k hova M.Ya., Z u b a t k i n a O.V. Efferentnaya terapiya, 2006, 1: 43-50.

24. Chernitski i A.E., S ide l'nikova V.I., Re tski i M.I. Veterinariya, 2014, 4: 56-58.

25. M ille r Yu.I., D o b r e t s o v G.E. Klinicheskaya i laboratornaya diagnostika, 1994, 5: $20-22$.

26. Smirnov S.V., M a t ve eva O.B., Golikov P.P., S p iridonova T.G., S mirnov K.S., Kly c hnik ov a E.V., N i k o l a v a N.Yu. Efferentnaya terapiya, 2003, 2: 33-37.

27. Yak ov lev M.Yu. Sistemnaya endotoksinemiya $v$ fiziologii i patologii cheloveka. Avtoreferat doktorskoi dissertatsii [Systemic endotoxemia in human physiology and pathology. DSc Thesis]. Moscow, 1993: 49-52.

28. Endotoxin in health and disease. H. Brade, S.M. Opal, S.N. Vogel, D.S. Morrison (eds.). NYBasel, 1999.

29. Yak o v lev M.Yu. Elements of endotoxin theory of human physiology and pathology: «systemic endotoxinemia», «endotoxin aggression» and «endotoxin insufficiency»? J. Endotoxin Res., 2000, 6(2): 120-131.

30. Yak o v le v M.Yu. Elements of endotoxin theory of human physiology and pathology. Human Physiology, 2003, 29(4): 476-486 (doi: 10.1023/A:1024989709554).

31. Khafip o u E E., Kraus e D.O., P laizie r J.C. A grain-based subacute ruminal acidosis challenge translocation of lipopolysaccharide and triggers inflammation. J. Dairy Res., 2009, 3: 1060-1070 (doi: 10.3168/jds.2008-1389).

32. M c Inty re C.W., H a r rison L.E.A., Eld e hi M.T., J e fferies H.J., Szoto O.C., John S.G., Sigrist M.K., B arton J.O., Hothi D., Korsheed S., Owe n P.J., La i K.B., Li P.K.T. Circulating endotoxinemia: a novel factor in systemic inflammation and cardiovascular disease in chronic kidney disease. Clin. J. Am. Soc. Nephrol., 2011, 6: 133-141 (doi: 10.2215/CJN.04610510).

33. Klut M.E., Wha le n B.A., Hogg J.C. Dynamic changes in neutrophil defenses during endotoxinemia. Infect. Immun., 2001, 69(12): 7793-7799 (doi: 10.1128/IAI.69.12.7793-7799.2001).

34. Erdama r H., Türközkan N., Ekremoğlu M., Ku rt Y., Yaman H. The effect of taurine on polymorphonuclear leukocyte functions in endotoxemia. Amino Acids, 2007, 4: 581585 (doi: 10.1007/s00726-007-0543-y).

35. Yagi H., Soto-Gutierrez A., Navarro-Alvarez N., Nahmias Y., Goldwasser Y., Kitagawa Y., Tilles A.W., Tompkins R.G., Parekkadan B., Yarmush M.L. Reactive bone marrow stromal cells attenuate systemic inflammation via sTNFR1. Mol. Ther., 2010, 18(10): 1857-1864 (doi: 10.1038/mt.2010.155).

36. Kamp V.M., Leentjens J., Pillay J., Langreis J.D., D e Kleyn S., Kox M., N e t e a M., Pikkers P., K o e nd e rma n L. Modulation of granulocyte kinetics by GMCSF, IFN in a human LPS rechallenge model. J. Leukoc. Biol., 2013, 3: 513-520 (doi: 10.1189/jlb.0213066).

37. He in H., Li e $\mathrm{n}$ E. Toll-like receptors and their function in innate and adaptive immunity. Int. Arch. Allergy Immunol., 2003, 130(3): 180-191 (doi: 10.1159/000069517).

38. D a u p i n e e S.M., K a r s a n A. Lipopolysaccharide signaling in endothelial cells. Lab. Invest., 2006, 86(1): 9-22 (doi: 10.1038/labinvest.3700366).

39. Khan K.N., Kitajja M., H eruki K., Fujjisit a A., S e kine I., Ishima ru T., $\mathrm{Masuzaki} \mathrm{H}$. Toll-like receptors in innate immunity: role of bacterial endotoxin and tolllike receptors-4 in endometrium and endometriosis. Gynecol. Obstet. Invest., 2009, 68(1): 4052 (doi: 10.1159/000212061).

40. Likhoded V.G., Yush u k N.D., Y a k ov lev M.Yu. Arkhiv patologii, 1996, 2: 8-13.

41. Endotoxins: structure, function and recognition. X. Wang, P. Quinn (eds.). Ser.: Subcellular Biochemistry. V. 53. Springer, 2010 (doi: 10.1007/978-90-481-9078-2).

42. Y a k o v le v M.Yu. Kazanskii meditsinskii zhurnal, 1988, 5: 353-357.

43. Pe r m y a k ov N.K., Y a k v lev M.Yu. Arkhiv patologii, 1989, 12: 74-79.

44. Anikhovskaya I.A., O parina O.N., Y a k ovleva M.M., Y a k ovlev M.Yu. Intestinal endotoxin as an universal factor of adaptation and pathogenesis of general adaptation syndrome. Human Physiology, 2006, 32(2): 200-203 (doi: 10.1134/S0362119706020149).

45. Ry abchenko E.V., B o ndare nko V.M. Zhurnal mikrobiologii, epidemiologii $i$ immunobiologii, 2007, 3: 103-111.

46. Harte A.L., Da Silva N.F., Creely S.J., Mc Ge e K.C., Billyard T., Yous sefElabd E.M., Tripathi G., Ashour E., Abdalla M.S., Sharada H.M., Amin A.I., Burt A.D., Ku ma r S., D a y C.P., M c Te rna n P.G. Elevated endotoxin levels in nonalkoholic fatty liver disease. J. Inflamm. (Lond.), 2010, 1: 15-20 (doi: 10.1186/1476-9255-7-15).

47. Oparina O.N., Anikhovskaya I.A., D evyataev A.M., Yakovleva M.M. Fiziologiya cheloveka, 2004, 1: 135-138. 
48. Apollonin A.V., Yakovlev M.Yu., Lik hoded V.G. Zhurnal mikrobiologii, epidemiologii i immunobiologii, 1990, 11: 100-106.

49. Y a k o vle v M.Yu. Uspekhi sovremennoi biologii, 2003, 1: 31-40.

50. Van der Meer W., Pickkers P., S cott C.S., Van der Hoeven J.G., Gunn e w i e k J.K. Hematological indices, inflammatory markers and neutrophil CD64 expression: comparative trends during experimental human endotoxemia. J. Endotoxin Res., 2007, 13(2): 94-100 (doi: 10.1177/0968051907079101).

51. B a hador M., Cross A.S. From therapy to experimental model: a hundred years of endotoxin administration to human subjects. J. Endotoxin Res., 2007, 13(5): 251-279 (doi: 10.1177/0968051907085986).

52. Trent M.S., Sle ad C.M., Tran A.X., H a n k is J.V. Deversity of endotoxin and its impact in pathogenesis. J. Endotoxin Res., 2006, 12(4): 205-223 (doi: 10.1177/09680519060120040201).

53. Enukidze G.G. Immunologiya, 2007, 6: 364-368.

54. Haynes T.E., Li P., Li X., Shimotori K., Sato H., Flynn N.E., Wang J., Knabe D.A., Wu G. L-Glutamine or L-alanyl-L-glutamine prevents oxidant- or endotoxininduced death of neonatal enterocytes. Amino Acids, 2009, 37(1): 131-142 (doi: 10.1007/s00726009-0243-x).

55. Quintro E.C., Cazita P.M. Lipid transfer proteins. Past, present and perspectives. Atherosclerosis, 2010, 209(1): 1-9 (doi: 10.1016/j.atherosclerosis.2009.08.002).

56. Akhmadullina Yu.A., Idrisova G.A., Mavzyutov A.P., Gil'manov A.Zh. Klinicheskaya i laboratornaya diagnostika, 2013, 9: 122.

57. Enukidze G.G., Anikhovskaya I.A., Marychev A.A., Yakovlev M.Yu. Antiendotoksinovoe napravlenie $v$ lechenii khronicheskogo vospaleniya $i$ zhenskogo besplodiya [Antiendotoxine approach in treatment of chronic inflammation and female infertility]. Moscow, 2006.

58. Olson N.C., Salze r W.L., M c Call C.E. Biochemical, physiological and clinical aspects of endotoxemia. Mol. Aspects Med., 1988, 10(6): 511-629 (doi: 10.1016/0098-2997(88)90024-6).

59. Liebers V., Raulf-Heimsoth M., Brüning T. Health effects due to endotoxin inhalation (review). Arch. Toxicol., 2008, 82(4): 203-210 (doi: 10.1007/s00204-008-0290-1).

60. Zebeli Q., Sivaraman S., Dunn S.M., Ametaj B.N. Intermittent parenteral administration of endotoxin triggers metabolic and immunological alterations typically associated with displaced abomasum and retained placenta in periparturient dairy cows. J. Dairy Sci., 2011, 94(10): 4968-4983 (doi: 10.3168/jds.2011-4194).

61. Möller W., Heimbeck I., Hofer T.P., Khadem Saba G., Neiswirth M., Frankenberger M., Ziegler-Heitbrock L. Differential inflammatory response to inhaled lipopolysaccharide targeted either to the airways or the alveoli in man. PLOS ONE, 2012, 7(4): e33505 (doi: 10.1371/journal.pone.0033505).

62. Buttenschoen K., Radermacher P., Bracht H. Endotoxin elimination in sepsis: physiology and therapeutic application. Langenbecks Arch. Surg., 2010, 395(6): 597-605 (doi: 10.1007/s00423-010-0658-6).

63. Gutsman T., Razquin-Olazaran L., Kowalski I., Kaconis Y., Honve J., Bartels R., Brandenburg K. New antiseptic peptides to protect against endotoxin-mediated shock. Antimicrob. Agents Chemother., 2010, 54(9): 3817-3824 (doi: 10.1128/AAC.00534-10).

64. Hurley J.C. Towards clinical applications of anti-endotoxin antibodies: a re-appraisal of disconnect. Toxins (Basel), 2013, 5(12): 2589-2620 (doi: 10.3390/toxins5122589).

65. Cross A.S. Anti-endotoxin vaccines: back to the future. Virulence, 2014, 5(1): 219-225 (doi: 10.4161/viru.25965).

66. Zimmermann M., Busch K., Kuhn S., Zeppezauer M. Endotoxin adsorbent based on immobilized human serum albumin. Clin. Chem. Lab. Med., 1999, 37(3): 373-379 (doi: 10.1515/CCLM.1999.062).

67. Gataullin Yu.K. Antiendotoksinovaya sostavlyayushchaya v profilaktike posleoperatsionnoi makrogematurii u detei s obstruktivnoi uropatiei. Avtoreferat kandidatskoi dissertatsii [Aniendotoxin component in preventing postoperative macrohematuria in children with an obstructive uropathy. PhD Thesis]. Moscow, 2012.

68. An ik hovskay a I.A., Gitaullin Yu.K., I va nov V.B., Khabriev R.U., Yakovle v M.Yu. Sposob opredeleniya soderzhaniya bakterial'nykh endotoksinov s ispol'zovaniem TAL-testa, $v$ kotorom registratsiyu obrazovaniya polimera koagulogena proizvodyat po strukture obrazuyushchikhsya fraktalov. Pat. 2325645 (RF) MPK G01N33/48, G01N33/579. ZAO «KDO-Test» (RF). № 2006141572/15. Zayavl. 13.11.2006. Opubl. 27.05.2008. Byul. № 15 [Assessment of bacterial endotoxines in TAL-test. Patent 2325645 (RF) MPK G01N33/48, G01N33/579. ZAO «KDO-Test» (RF). № 2006141572/15. Published 27.05.2008. Bul. № 15].

69. Zinkevich O.D., Anikhovskaya I.A., S S fina N.A., Krupnik A.N., $\mathrm{S}$ a la khov I.M., U ra za ev R.A., K h abriev R.U., Y a kov lev M.Yu. Sposob opredeleniya aktivnosti endotoksina (varianty). Pat. 2169367 (RF) MPK G01N33/48, G01N33/487, G01N33/49, G01N33/579. ZAO "Kliniko-diagnosticheskoe obshchestvo» (RF). № 2000121576/14. Zayavl. 16.08.2000. Opubl. 20.06.2001. Byul. № 17 [Assessment 
of endotoxine activity (modifications). Patent 2169367 (RF) MPK G01N33/48, G01N33/487, G01N33/49, G01N33/579. ZAO «Kliniko-diagnosticheskoe obshchestvo» (RF). № 2000121576/14. Published 20.06.2001. Bul. № 17].

70. B o ndare nko V.M., Likh od ed V.G., Yakovlev M.Yu. Zhurnal mikrobiologii, epidemiologii i immunobiologii, 2002, 2: 83-89.

71. B o k e ri y a L.A., Ni y a $\mathrm{z}$ a t ov A.A., S a m so nova N.N., S a mu i lova D.Sh. Serdechno-sosudistye zabolevaniya (byulleten' NTSSSKh im. A.N. Bakuleva RAMN), 2004, 5(11): 266

72. B is w a s S.K., Lo pe z-C o 11 a z o E. Endotoxin tolerance: new mechanisms, molecules and clinical significance. Trends Immunol., 2009, 30(10): 475-487 (doi: 10.1016/j.it.2009.07.009).

73. Likhoded V.G., Yakovlev M.Yu., A pollonin A.V., Kozlova N.N., $\mathrm{Kudry}$ avtsev A.E., Y u s hu k N.D. Sposob otsenki sostoyaniya antiendotoksinovogo immuniteta $V$ otnoshenii gramotritsatel'nykh bakterii (LPS-TEST-IFA). Pat. 2088936 (RF) MPK G01N33/53. Nauchno-investitsionnaya kompaniya «Mechnikov» (RF). № 94014519/14. Zayavl. 18.04.1994. Opubl. 27.08.1997. Byul. № 24 [Evaluation of anti-endotoxine immunity against gram-negative bacteria (LPS-TEST-IFA). Patent 2088936 (RF) MPK G01N33/53. Nauchno-investitsionnaya kompaniya «Mechnikov» (RF). № 94014519/14. Published 27.08.1997. Bul. № 24].

74. Petzl W., Gi inter J., Pfister T., S a u ter-Lonis C., Goetze L., Von A u lock S., Hafner-M arx A., S chuberth H.-J., S e y fert H.-M., Zerbe H. Lipopolysaccharide pretreatment of the udder protects against experimental Escherichia coli mastitis. Innate Immun., 2012, 18(3): 467-477 (doi: 10.1177/1753425911422407). 